International Journal of Agriculture, Environment and Bioresearch

Vol. 4, No. 06; 2019

ISSN: $2456-8643$

\title{
PERCEPTION ON NEW PADDY VARIETY AMONG PADDY FARMERS IN TERENGGANU, MALAYSIA
}

\author{
Nur Syuhada Zanuldin and Zainal Abidin Mohamed \\ Department of Agribusiness and Bioresource Economics, Faculty of Agriculture, Universiti Putra Malaysia ,43400 \\ UPM Serdang \\ http://doi.org/10.35410/IJAEB.2019.4494
}

\begin{abstract}
This paper employed survey data to identify paddy farmers' perception towards new paddy variety in IADA KETARA granary area in Terengganu, Malaysia. Systematic random sampling techniques was used to select the respondents. Face-to-face interview among 110 respondents was conducted by using structured questionnaire. The objective of this study is to investigate paddy farmers' perception towards new paddy variety. The results show that socio-demographic of respondents in IADA KETARA area represents $98.2 \%$ of respondents are male and the rest of $1.8 \%$ are female farmers. The most predominant age group of the respondents are between 41 to 50 years old represents $28.2 \%$. About $62.7 \%$ of respondents were secondary educated, $27.3 \%$ primary educated, $5.5 \%$ non-formal educated and $4.5 \%$ were tertiary educated. The mean value analysis considered that farmers have positive perception as the overall mean value for advantages statement is 5.44 while mean value for disadvantages statement is 4.21 . Chi-square analysis found that there are significant association between farmers' age, education level and farm assistant towards knowledge about new paddy variety.
\end{abstract}

Keywords: Mean value, new paddy variety, paddy farmers, perception.

\section{INTRODUCTION}

Paddy is an important major food crop in Malaysia since rice is an important source of food in supplying energy sources as increasing number of human population. Due to its strategic importance of rice as the Malaysian staple food, it were undertaken as the government responsibilities which make this industry often receive massive attention and seriously emphasized by the government. According to the Ministry of Agriculture and Agro-Based (2018)[16], the paddy farming occupied approximately more than 680 thousand hectares of total agricultural land in Malaysia. The production of yield is estimated to be around 3,000 metric tons in 2018 with average yield at 4.443 tons per hectares (DOA, 2018)[3]. However it is still insufficient to accommodate the needs of the domestic consumption. It is inevitable for Malaysia to import rice to meet the domestic demand and the task was given to BERNAS as a government link company (Othman, 2007). Currently Malaysia needs to import rice from neighbour countries like Thailand, Cambodia and Vietnam. In 2017, the total rice imports is about 900,000 tons (DOA, 2018)[3]. 
In 2007, the world was faced food crisis which caused many countries to significant decrease in rice production. This experienced has made Malaysian government taking further step in strengthening the food security by increasing the rice production yield. It is being the main focus in agriculture sector. The Malaysian self-sufficiency level (SSL)which is at about $70 \%$ is not parallel with the increasing of country's growth population (MARDI, 2013). Based on Table 1, the SSL in 2017 is at about 71.5\%, which targeted to be $75 \%$ in 2018 and $77 \%$ in 2019 (MOA, 2019).Farmers had need to increase the current crop yield of 4-6 tons to 7 tons per hectare (MOA, 2015)[16]. Simultaneously, Fatimah Mohamed Arshad[18] in National Paddy Conference 2017 declared that the rice production is targeted to be $100 \%$ self-sufficient in 2050 .

Table 1: Paddy and Rice Information in Malaysia, 2014 - 2018

\begin{tabular}{|l|l|l|l|l|l|}
\hline Item /Year & $\mathbf{2 0 1 4}$ & $\mathbf{2 0 1 5}$ & $\mathbf{2 0 1 6}$ & $\mathbf{2 0 1 7}$ & $\mathbf{2 0 1 8}^{\mathbf{e}}$ \\
\hline Production of paddy ('000 mt) & 2,845 & 2,741 & 2,740 & 2,568 & 3,065 \\
\hline Production of rice ('000 mt) & 1,835 & 1,767 & 1,766 & 1,655 & 1,976 \\
\hline Average yield (t/ha) & 4.194 & 4.022 & 3.978 & 3.728 & 4.443 \\
\hline Self-sufficiency level (SSL) of rice & 71.6 & 71.5 & 71.5 & 71.5 & 75.0 \\
\hline
\end{tabular}

Note: $e=$ estimated data

Source: DOA (2018)

IADA KETARA (Integrated Agriculture Development Area of North-west Terengganu) is one of the main granary areas that have an important task to increase the yield productivity particularly from average of 4.5 tons per hectare to 6 tons per hectare (MOA, 2017). Granary areas refer to major irrigation schemes with areas greater than 4,000 hectares. It was recognized by the government in the National Agricultural Policy (NAP) as the main paddy producing areas. Based on Table 2, the average yield estimated for IADA KETARA is at 6.687 tons per hectare in 2018. However, the average yield for other granary areas except IADA Barat Laut Selangor and IADA Pulau Pinang were estimated to be lower than 6 tons per hectare (DOA, 2018)[3] according to their potential productivity at current situation. The production of rice was in fluctuation trend since 1980s because of several reasons (DOA, 2018)[3]. It could be due to the low and unstable average farm productivity, seed quality, biotic and abiotic constraints, weed and weedy rice problems, climatic change, water supply and water management and also harvesting losses (MARDI, 2015)[14]. The average yield for all granary areas is estimated to be at 5.507 tons per hectare (DOA, 2018)[3]. 
Table 2: Average Yield of Wetland Paddy by Granary Areas in Peninsular Malaysia, 20142018

\begin{tabular}{|l|l|l|l|l|l|}
\hline \multirow{2}{*}{ Granary Area } & \multicolumn{5}{|l|}{ Year / Average Yield (t/ha) } \\
\cline { 2 - 6 } & $\mathbf{2 0 1 4}$ & $\mathbf{2 0 1 5}$ & $\mathbf{2 0 1 6}$ & $\mathbf{2 0 1 7}$ & $\mathbf{2 0 1 8}$ \\
\hline KADA & 5.539 & 4.884 & 5.284 & 4.841 & 5.892 \\
\hline IADA Kerian & 4.297 & 4.442 & 4.610 & 4.448 & 5.124 \\
\hline IADA BLS & 4.514 & 4.508 & 3.949 & 4.087 & 4.414 \\
\hline IADA P.Pinang & 6.403 & 6.305 & 5.825 & 4.510 & 6.512 \\
\hline IADA Seberang Perak & 5.872 & 5.866 & 5.801 & 5.737 & 6.571 \\
\hline IADA Ketara & 4.484 & 3.956 & 3.729 & 3.180 & 4.169 \\
\hline IADA Kemasin Semarak & 5.738 & 5.437 & 5.623 & 5.172 & 6.487 \\
\hline IADA Pekan & 3.715 & 3.781 & 3.771 & 3.779 & 4.192 \\
\hline IADA Rompin & 2.671 & 2.571 & 2.052 & 1.357 & 2.113 \\
\hline IADA Kota Belud & 3.442 & 4.014 & 2.793 & 3.147 & 2.876 \\
\hline IADA Batang Lupar & - & - & - & 2.511 & 2.511 \\
\hline Average & - & - & - & 2.009 & 2.009 \\
\hline
\end{tabular}

Note: $e=$ estimated data

$$
B L S=\text { Barat Laut Selangor }
$$

Source: DOA (2018)

Improving paddy seed quality is deemed one of the effective efforts to increase productivity that has being driven by the government. According to MARDI (2015)[14], the introduction of new variety is expected to have a positive impact on yield. The traditional paddy seeds were issued with low yield, long maturity days, less resistance to pest and diseases and moderate quality (MOA, 2015)[14]. Thus, the traditional quality of paddy seeds were improved to get higher yield potential, more resistance to pest and diseases and better quality of rice produced. Particularly, the improvement of high yield varieties have make it suitable for double cropping and multiple cropping which can helps in resulting of high productivity as well as saving lands. 
However, the use of farm chemicals like pesticides has tremendously increased over the years. Consequently, the excessive usage of farm chemicals like pesticides had make pests becoming resistant to the chemicals. In order to reduce the infestation, the seed varieties that are resistant to pest and diseases are being used (Hassan, 2012)[9]. One of the serious and main diseases that has been assault paddy plant is blast disease which is a major contributed of low productivity of paddy in Malaysia as well as other 85 paddy growing countries (Hassan, 2017)[8]. Thus, new high yield varieties have been developed as the solution and alternative to increase the production yield.

Statistical data recorded that there were seven paddy varieties that have been popular planted among the farmers from 2010 to 2015. It consists of MR219, MR220, MR232, MR263, MR284, MR220CL1 and MR220CL2 (DOA, 2016). Variety MR219 and MR220 were the most common varieties planted by Malaysian farmers for more than 12 years with significant contribution of increasing production (Talib and Kadir, 2014[25]; MARDI, 2011[15]; Suswanto et al., 2007[24]). But, the assault of panicle blast disease has been seriously detected in MR219 and MR220 since 2003. Due to that, MARDI has developed and released some new varieties like MR253, MR284, MR263, MR269 and MR Siraj 297 in order to tackle the problem of blast disease that assaulted paddy plant.

Simultaneously in 2016, a new paddy technology known as PadiU Putra has been developed by a group of researchers from Universiti Putra Malaysia (UPM). Under this package technology, there is a new paddy variety namely Putra 1 that has been developed. This new variety is developed to be more tolerant to pest and diseases especially blast disease as well as have high potential yield up to 10 tons per hectare (ITAFoS UPM, 2017)[11].

Thus, it is worthwhile to investigate paddy farmers' perception about Putra 1 before embarking on the Putra 1 in large scale. Since it is a new technology, thus it is timely to explore the criteria that could determine the farmers' perception about this new paddy variety. Farmers' opinion on the potential of Putra 1 as a more blast disease tolerant, high potential yield as well as income enhancer are worth to look at as it still at the stage of early adopter.

\section{LITERATURE REVIEWS}

The literature reviews have disclosed that Malaysian studies on respondents that have positive perception on urban agriculture significantly have an intention to practice it in the future (Ngahdiman et al., 2017)[21].Likewise, positive opinion about Clearfield Rice Production System was being the determinant for paddy farmers in KADA area to adopt new paddy variety MR 220CL2 (Terano et al., 2016)[27]. Likewise, farmers in Muda Agricultural Development Authority (MADA) Malaysia were got significant impacted by their age and years of involvement on their level of practices using new paddy variety (Nazuri and Man, 2016)[20].

Similarly, the perception on innovation characteristics significantly contributes to the adoption behaviour. Positive perceptions of farmers in Madhya Pradesh, India on organic coconut farming is tend to have high adoption rate of innovations (Patidar and Patidar, 2015)[22]. 
Individual characteristics such as demographic factors like age, education and farm size will also influenced farmers' perception and adoption decision of innovation as well as their attitude towards organic farming (Patidar and Patidar, 2015)[22]. Apart from that, farmers' knowledge give significant effect to their willingness in adopting new chicken feed formulation in West Malaysia study area as being claimed by Mohamad et al. (2015)[17]. Simply put, farmers that have knowledge is ready to accept innovation compared to unacknowledged farmers.

The studies conducted by Bruce et al. (2015)[2] in Ghana shows that farmers that have formal education, household size and smallholder farms positively influenced the adoption of improved rice variety.

Asante et al. (2013)[1] disclosed that farmers' preferred rice varieties with high yield potential and excellent grain quality based on studies at Ashanti region of Ghana. He further notes that plant height, thresh ability, disease resistance and weed competitiveness were the other important traits that being considered in selecting a variety. Besides, a studies conducted by Jamal et al. (2013)[12] disclosed that farmers in the East Coast, Malaysia showed a positive acceptance attitude on the cultivation of the new paddy variety, MRQ 74.

The location of operation and farm size have significant effects on growers' adoption of sustainable practices (Hall and Rhoades, 2010)[7]. Perception or attitude is an individual's positive or negative evaluation of self-performance on a particular behaviour (Luthans and Avolio, 2009)[13].The weak and negative perceptions of technology disorganization, geographical conditions, lack and inadequate resources and funds, small land area and low education level has led to low technology adoption (Truong, 2008)[28].

Besides, the adoption of new practices like conservation programs and organic production were negatively influenced as the increase of grower's age, but positively influenced by education levels (Hattam, 2006)[10]. Besides, Simpkins et al. (2005)[23] reported that demographic variables were predictor of youth participation in urban agriculture activity. Other factors like demographic characteristics and prior experience is considered as important assumed to the formation of intentions.

\section{METHODOLOGY}

Theory of planned behaviour (TPB) was used to construct the theoretical framework for this study. This study was conducted by face to face interviews with paddy farmers in IADA KETARA granary area in Terengganu. Systematic random sampling techniques was used to select the respondents for this study. One hundred and ten (110) paddy farmers who have been involved in the awareness campaign such attending seminar and talk by UPM researchers and extension agents were selected. The data was collected through interviewed to gather information from paddy farmers via structured questionnaire between April 2017untilMay 2017.

The questionnaire included the socio-demographic, farm profile, knowledge and perception. The perception about advantages and disadvantages about new paddy variety is based on attitudinal Likert scale of 1 to 7. Descriptive analysis was performed to discover the sociodemographic background of the paddy farmers. The Chi-square analysis was employed to 
examine the association between respondents' socio-demographic profiles and knowledge.The general hypothesis test could be expressed as follows:

$\mathrm{H}_{0}: \beta 0=\beta 1=\beta 2=\ldots \ldots .=\beta_{p}=0$

$\mathrm{H} 1: \beta 1 \neq 0$ for at least one $\mathrm{i}$

$\mathrm{i}=1,2, \ldots ., \mathrm{p}$

The null hypothesis (H0) was explained as there is no significant association betweendependent variable (knowledge) with independent variables (such as age, educationlevel, types of farmer, marital status, farming experience and household number). While alternative hypothesis $\left(\mathrm{H}_{1}\right)$ was explained as there is significant associationbetween dependent and independent variables. The hypothesis for this study can be simplified asfollows:

$\mathbf{H}_{\mathbf{0}}=$ There is no significant association between socio-demographic profiles andfarmers' knowledge about new paddy variety (Putra 1)

$\mathbf{H}_{1}=$ There is a significant association between socio-demographic profiles andfarmers' knowledge about new paddy variety (Putra 1)

\section{RESULTS AND DISCUSSION}

\section{Descriptive Analysis}

Based on the Table 3, those age group within 41 to 50 years old was the most predominant age $(\mathrm{n}=31,28.2 \%)$, followed by those above 60 years old $(\mathrm{n}=27,24.5 \%), 31$ to 40 years old $(\mathrm{n}=23$, $20.9 \%), 51$ to 60 years old $(n=16,14.5 \%)$ and 21 to 30 years old $(n=13,11.8 \%)$. Majority of respondents was dominated by male farmers $(n=108,98.2 \%)$. Most of them have completed secondary education as their educational background $(n=69,62.7 \%)$. Majority of respondents have less than 5 household number $(\mathrm{n}=56,50.9 \%)$. Most of respondents work as a full-time paddy farmer $(\mathrm{n}=80,72.7 \%)$ and the rest were part-timer paddy farmers $(\mathrm{n}=30,27.3 \%)$. Apart from that, majority of respondents have farm size less than 5 acres $(n=51,46.3 \%)$. Most of them have more than 16 years experience in paddy farming $(n=29,26.4 \%)$. Majority of respondents are preferred family members as their farm assistant $(n=89,80.9 \%)$.

Table 3:Respondents' Characteristics

\begin{tabular}{|l|l|l|}
\hline Characteristics & Frequency $(\mathbf{n}=110)$ & Percentage (\%) \\
\hline Age (Years old) & & \\
$21-30$ & 13 & 11.8 \\
$31-40$ & 23 & 20.9 \\
$41-50$ & 31 & 28.2 \\
$51-60$ & 16 & 14.5 \\
\hline
\end{tabular}


International Journal of Agriculture, Environment and Bioresearch

Vol. 4, No. 06; 2019

ISSN: $2456-8643$

\begin{tabular}{|c|c|c|}
\hline Above 60 & 27 & 24.5 \\
\hline \multicolumn{3}{|l|}{ Gender } \\
\hline Male & 108 & 98.2 \\
\hline Female & 2 & 1.8 \\
\hline \multicolumn{3}{|l|}{ Marital status } \\
\hline Married & 97 & 87.2 \\
\hline Single & 13 & 11.8 \\
\hline \multicolumn{3}{|l|}{ Education level } \\
\hline Non-formal & 6 & 5.5 \\
\hline Primary school & 30 & 27.3 \\
\hline Secondary school & 69 & 62.7 \\
\hline Tertiary school & 5 & 4.5 \\
\hline \multicolumn{3}{|l|}{ Household number } \\
\hline Less than 5 & 56 & 50.9 \\
\hline $5-10$ & 46 & 41.8 \\
\hline 11 and above & 8 & 7.3 \\
\hline \multicolumn{3}{|l|}{ Types of farmer } \\
\hline Full-timer & 80 & 72.7 \\
\hline Part-timer & 30 & 27.3 \\
\hline \multicolumn{3}{|l|}{ Farm size (acre) } \\
\hline $1-5$ & 51 & 46.3 \\
\hline $6-10$ & 41 & 37.3 \\
\hline $11-15$ & 10 & 9.1 \\
\hline 16 and above & 8 & 7.3 \\
\hline Farming experience & & \\
\hline
\end{tabular}




\begin{tabular}{|l|l|l|}
\hline $1-5$ & 18 & 16.3 \\
$6-10$ & 29 & 26.4 \\
$11-15$ & 18 & 16.3 \\
16 and above & 45 & 41.0 \\
\hline Farm assistant & 89 & 80.9 \\
Family member & 21 & 19.1 \\
Hired labour & & \\
\hline
\end{tabular}

Note: $n=110$

Table 4 on the other hand shows the mean value analysis result of respondents' perception towards new paddy variety. Thus, by referring to the mean, the result shows that the respondents have positive responses as the mean values for most of the advantages statements were ranged between 5.0 to $6.0(5.0=$ slightly agree and $6.0=$ agree $)$ except the statement "easyto manage and cultivate" which scored a mean value below 5.0. The highest mean value showed by "increase farmers' income" (5.86), followed by "increase the cropyield" (5.65), "more resistant to blast disease" (5.63), "help control pest and diseases infestation" (5.51), "high quality produce" (5.41), "minimum fertilizer" (5.40) and"easy to cultivate and manage" (4.91). In overall, the total mean value scored for advantages statements was 5.44. Whereas, for all the disadvantages statements were ranged between 3.0 to $6.0(2.0=$ disagree and $3.0=$ slightly disagree, $4.0=$ either agree or disagree, $5.0=$ slightly agree, $6.00=$ agree). Four statements were ranged between 3.0 to 4.0; "low seed germination" (3.44), followed by "new variety is risky" (3.99), "require frequent pesticiding" (3.93), and "require more fertilizer" (3.95). While "doubtful with seed quality" has scored a mean value of 4.53 and "the seed is difficult to access" is 5.56.In overall, the total mean value scored for disadvantages was 4.21.

In summary, the total mean of advantages was more than the mean value scored by disadvantages, thus we can conclude that there is a positive perception towards newpaddy variety specifically Putra 1 among the paddy farmers in that study area.

Table 4:Respondents' Perception towards Advantages and Disadvantages of New Paddy Variety (Putra 1)

\begin{tabular}{|l|l|l|l|l|l|l|l|l|l|}
\hline \multirow{2}{*}{ Statements } & \multicolumn{9}{|l|}{ Scale (\%) } \\
\cline { 2 - 10 } & $\mathbf{1}$ & $\mathbf{2}$ & $\mathbf{3}$ & $\mathbf{4}$ & $\mathbf{5}$ & $\mathbf{6}$ & $\mathbf{7}$ & Mean & S.D \\
\cline { 1 - 3 } & & & & & & & & & \\
\hline Increase the crop yield & 0.0 & 0.9 & 0.9 & 10.9 & 24.5 & 44.5 & 18.2 & 5.65 & 0.990 \\
\hline
\end{tabular}


ISSN: $2456-8643$

\begin{tabular}{|c|c|c|c|c|c|c|c|c|c|}
\hline $\begin{array}{ll}\text { Increase } & \text { farmers' } \\
\text { income } & \end{array}$ & 0.0 & 0.0 & 0.0 & 9.1 & 20.9 & 44.5 & 25.5 & 5.86 & 0.903 \\
\hline $\begin{array}{l}\text { Help control pest and } \\
\text { diseases }\end{array}$ & 0.0 & 0.9 & 6.4 & 10.9 & 22.7 & 40.9 & 18.2 & 5.51 & 1.155 \\
\hline $\begin{array}{l}\text { More resistant to blast } \\
\text { disease }\end{array}$ & 0.0 & 0.0 & 1.8 & 17.3 & 20.0 & 38.2 & 22.7 & 5.63 & 1.074 \\
\hline $\begin{array}{l}\text { Reduce the use of } \\
\text { pesticides }\end{array}$ & 0.0 & 4.5 & 5.5 & 10.0 & 23.6 & 42.7 & 13.6 & 5.35 & 1.260 \\
\hline $\begin{array}{ll}\text { Minimum } & \text { fertilizer } \\
\text { required } & \end{array}$ & 0.0 & 1.8 & 0.0 & 10.0 & 36.4 & 48.2 & 3.6 & 5.40 & 0.859 \\
\hline $\begin{array}{l}\text { Reduce the cost of } \\
\text { fertilizer and pesticides }\end{array}$ & 0.0 & 9.1 & 5.5 & 10.0 & 20.0 & 37.3 & 18.2 & 5.25 & 1.480 \\
\hline High quality produce & 0.0 & 0.0 & 1.8 & 23.6 & 19.1 & 42.7 & 12.7 & 5.41 & 1.043 \\
\hline $\begin{array}{l}\text { Easy to cultivate and } \\
\text { manage }\end{array}$ & 0.0 & 5.5 & 10.0 & 23.6 & 17.3 & 25.5 & 16.4 & 4.91 & 1.530 \\
\hline \multicolumn{8}{|l|}{ Total Mean } & 5.44 & 1.144 \\
\hline \multicolumn{10}{|l|}{ Disadvantages } \\
\hline $\begin{array}{l}\text { The seed is difficult to } \\
\text { access }\end{array}$ & 0.0 & 5.5 & 2.7 & 14.5 & 11.8 & 38.2 & 27.3 & 5.56 & 1.385 \\
\hline Low seed germination & 7.3 & 24.5 & 27.3 & 20.0 & 7.3 & 6.4 & 7.3 & 3.44 & 1.611 \\
\hline New variety is risky & 5.5 & 15.5 & 23.6 & 17.3 & 10.0 & 24.5 & 3.6 & 3.99 & 1.667 \\
\hline $\begin{array}{lll}\begin{array}{l}\text { Doubtful with } \\
\text { quality }\end{array} & & \end{array}$ & 0.9 & 10.0 & 12.7 & 28.2 & 18.2 & 20.0 & 10.0 & 4.53 & 1.494 \\
\hline Require more fertilizer & 1.8 & 10.9 & 30.0 & 24.5 & 17.3 & 10.9 & 4.5 & 3.95 & 1.391 \\
\hline $\begin{array}{ll}\text { Require } & \text { frequent } \\
\text { pesticiding } & \end{array}$ & 0.0 & 20.0 & 22.7 & 26.4 & 11.8 & 13.6 & 5.5 & 3.93 & 1.482 \\
\hline \multicolumn{8}{|l|}{ Total Mean } & 4.21 & 1.453 \\
\hline \multicolumn{8}{|l|}{ Overall Mean } & 4.952 & 1.267 \\
\hline
\end{tabular}

Note: $n=110$

$$
1=\text { Strongly disagree, } 2=\text { Disagree, } 3=\text { Slightly disagree, } 4=\text { Either agree or }
$$




$$
\text { disagree, } 5=\text { Slightly agree, } 6=\text { Agree, } 7=\text { Strongly agree }
$$

\subsection{Chi-Square Analysis}

Chi-square analysis was used to measure the association between farmers' knowledge and their socio-demographic profiles. There was a hypothesis developed for this analysis;

$\mathrm{H}_{0}=$ There is no association between farmers' knowledge and socio-demographic profiles.

$\mathrm{H}_{1}=$ There is an association between farmers' knowledge and socio-demographic profiles.

Table 5 shows the result of association between farmers' knowledge about new paddy variety (Putra 1) and their demographic profiles. Based on the table, it shows that only age, education level and farm assistant are significant to farmers 'knowledge about new paddy variety (Putra 1). As they are significant, it means that there is an association between farmers' knowledge and demographic profiles(alternative hypothesis). Thus, null hypothesis for age, education level and farm assistant were rejected. Age was significant at 5 percent level of significance with significant value of 0.037 , whilst education level (0.001) and farm assistant (0.008)were significant at 1 percent level of significance. However, other variables such as marital status, household number, types of farmer, farm size and farming experience were found not significant. It means, these variables have no association with farmers' knowledge. Thus, the null hypothesis (H1) is failed to reject. This finding is in line with Terano et al. (2016) that knowledge farmers were influenced by demographic profiles.

Table 5: Association between Knowledge towards New Paddy Variety (Putra 1) and Demographic Profiles of Respondents

\begin{tabular}{|l|l|l|l|l|}
\hline Variables & Chi-Square Value & df & Significant & Decision \\
\hline Age & 10.209 & 4 & $0.037^{* *}$ & Reject $\mathrm{H}_{0}$ \\
\hline Education level & 15.560 & 3 & $0.001^{* * *}$ & Reject $\mathrm{H}_{0}$ \\
\hline Marital status & 0.241 & 1 & 0.624 & Fail to reject $\mathrm{H}_{0}$ \\
\hline Household number & 0.135 & 2 & 0.935 & Fail to reject $\mathrm{H}_{0}$ \\
\hline Types of farmer & 0.131 & 1 & 0.718 & Fail to reject $\mathrm{H}_{0}$ \\
\hline Farm size & 0.813 & 3 & 0.846 & Fail to reject $\mathrm{H}_{0}$ \\
\hline Farming experience & 0.497 & 3 & 0.920 & Fail to reject $\mathrm{H}_{0}$ \\
\hline Farm assistant & 6.990 & 1 & $0.008^{* * *}$ & Reject $\mathrm{H}_{0}$ \\
\hline
\end{tabular}

Note: ***Significant at $1 \%$ level of significance 
**Significant at $5 \%$ level of significance

\section{CONCLUSION\& RECOMMENDATIONS}

Based on the results of descriptive analysis, majority of respondents were dominated by male farmers, secondary educated, full-timer paddy farmers and have more than 16 years of experience in paddy farming. The mean value analysis showed the respondents' perception towards new paddy variety. The responses in each statement of perception towards advantages and disadvantages of selected new paddy variety was identified. From theanalysis, it showed that paddy farmers do have positive perception as the mean values for all advantages statements were ranged (5.44) higher than mean values scored by all disadvantages statements (4.21).

Chi-square analysis was performed in order to examine the association between respondents' socio-demographic profiles (age, education level, marital status, household number, types of farmer, farming experience, farm assistant) and respondents' knowledge on new paddy variety (Putra 1). The result of this analysis indicated that age, education level and farm assistant were significant associated with knowledge.

Results from this study can be a guideline for authorities in getting a road map on how to sustain and increase the adoption on new seed varieties among paddy farmers. Providing seminar and training for the farmers for encouraging better attitude and improving their knowledge about new technologies will consequently improve the adoption so thus the yield. This information also can be used for implementing development program according to the farmers' level and capabilities . So thus, it could help to facilitate the farmers to be more understand while exploring the technology.

\section{REFERENCES}

[1] Asante, M. D., Asante, B. O., Acheampong, G. K., Wiredu, A. N., Offei, S. K., Gracen, V., \& Danquah, E. Y. (2013). Grain quality and determinants of farmers preference for rice varietal traits in three districts of Ghana: implications for research and policy. Journal of Development and Agricultural Economics, 5(7), 284-294.

[2] Bruce, A. K. K., Donkoh, S. A., Ayamga, M. (2014). Improved rice variety adoption and its effects on farmers, output in Ghana. JDev Agric Econ, 6(6), 242-248.

[3] Department of Agriculture. (2018). Booklet Statistik Tanaman 2018. Retrieved from http://www.doa.gov.my//index/resources/aktiviti_sumber/sumber_awam/maklumat_pertani an/perangkaan_tanaman/booklet_statistik_tanaman_2018.pdf

[4] Department of Agriculture (2017). Perosak Tanaman Padi. Retrieved from http://www.doa.gov.my/index/resources/aktiviti_sumber/sumber_awam/maklumat_biosekur iti/perosak_tanaman_padi.pdf

[5] Department of Agriculture (2016). Perangkaan Padi Malaysia 2015 (Paddy Statistics of Malaysia 2015). Retrieved from 
http://www.doa.gov.my/index/resources/aktiviti_sumber/sumber_awam/maklumat_pertania n/perangkaan_tanaman/perangkaan_padi_2015.pdf

[6] Efisue, A., Tongoona, P., Derera, J., Langyintuo, A., Laing, M., \& Ubi, B. (2008). Farmers' perceptions on rice varieties in Sikasso region of Mali and their implications for rice breeding. Journal of Agronomy and Crop Science, 194(5), 393-400.

[7] Hall, K., Rhoades, E., (2010). Influence of subjective norms and communication preferences on grain farmers' attitudes toward organic and non-organic farming. Journal of Applied Communication, 94, 3. Doi:10.4148/1051-0834.1192.

[8] Hassan, N., A. (2017). Magnaphorthe oryzae - Fungus pencetus penyakit karah padi. Majalah Sains.

[9] Hassan, Z. A. (2012). Issues and challenges: Strategies to sustain rice industry through R \& D. Rice and Industrial Crops Research Centre, MARDI Serdang, Selangor.

[10] Hattam, C. Adopting organic agriculture: An investigation using the Theory of Planned Behaviour. Paper presented at the International Association of Agricultural Economics Conference, Gold Coast, Australia, August 12-18, 2006.

[11] Institute Tropical Agriculture and Food Security Universiti Putra Malaysia (2017). Inovasi teknologi PadiU Putra. Retrieved from http://www.itafos.upm.edu.my/artikel/inovasi_teknologi_padiu_putra-33057?L=bm

[12] Jamal, K., Kamarulzaman, N. H., Abdullah, A. M., Ismail, M. M., and Hashim, M. (2013). Farmers' acceptance towards fragrant rice farming: The case of non-granary areas in the east coast, Malaysia. Journal of International Food Research, 20(5), 2895-2899.

[13] Luthans, F., Avolio, B. J. (2009). The "point" of positive organizational behavior. Journal Organizational Behavior, 30, 291-307.

[14] Malaysian Agriculture Research Development Institute (2015). Retrieved from http://padi.mardi.gov.my/dokumen/slide/L2\%20ke\%20arah\%20negara\%20pengeksportan\% 20beras_Fatimah\%20(UPM).pdf

[15] Malaysian Agriculture Research Development Institute (2012). Inisiatif inovasi dikenal pasti: padi varieti baru. Retrieved from https://www.mardi.gov.my/

[16] Ministry of Agriculture and Agro-based Industry (2018). Paddy and rice division. Retrieved from http://www.moa.gov.my/bahagian-industri-padi-dan-beras/

[17] Mohamad, S. F., Mohamed, Z. A., Rezai, G., Sharifuddin, J. (2015). Farmers willingness to adopt new feed formulation: Poultry industry in Malaysia. Masters Thesis, Universiti Putra Malaysia.

[18] Mohamed, Arshad, F., Alias, E. F., Mohd Noh. K., \& Muhammad Tasrif. (2011). Food security: Self-sufficiency of rice in Malaysia, 1(18), 83-100. 
[19] National Agro Food Policy 2011-2020. Retrieved from http://www.moa.gov.my/documents/20182/29029/Ringkasan+Eksekutif-DANemail.pdf/57f992fc-3e97-493b-a5b1-9b2cb0f87cc5

[20] Nazuri, N. S., \& Man, N. (2016). Acceptance and practices on new paddy seed variety among farmers in MADA granary area. Academic Journal of Interdisciplinary Studies, $5(2), 105-110$.

[21] Ngahdiman, I. N., Terano, R., Mohamed, Z., \& Sharifuddin, J. (2017). Factors affecting urban dwellers to practice urban agriculture. International Journal of Advanced Research (!JAR), 5(7), 1580-1587. Doi:10.21474/ijar01/4872.

[22] Patidar, S., \& Patidar, H. (2015). A study of perception of farmers towards organic farming. International Journal of Application or Innovation in Engineering \& Management, 4(3), 269-277.

[23] Simpkins, S. D., Ripke, M., Huston, A. C., \& Eccles, J. S. (2005). Predicting participation and outcomes in out-of-school activities: Similarities and differences across social ecologies. New directions for youth development. 105, 51-69.

[24] Suswanto, T., J. Shamshuddin, S. R. Syed Omar \& P. Mat. (2007). Effects of lime and fertilizer application in combination with water management on rice (Oryza Sativa) cultivated on an acid sulphate oil. Mediterranean Journal of Social Sciences, 11, 1-16.

[25] Talib, R., Kadir, Z. A. (2014). The training course for dust test of rice: Situation breeding and production of rice in Malaysia. Hanoi, Vietnam.

[26] Terano, R., Mohamed, Z. A., Shamsudin, M. N., Abdul, Latif. I., (2015). Factors influencing intention to adopt sustainable agriculture among paddy farmers in KADA, Malaysia. Asian Journal of Agricultural Research, 9(5), 268-75. Doi: 10.92/ajar.2015.268.275.

[27] Terano, R., Mohamed, Z., and Zanuldin, N. S. (2016). Determinants of farmers' adoption of Clearfield production system in Malaysia. Agriculture and Agricultural Science Procedia, 9, 103-107.

[28] Truong, T. N. C. (2008). Factors affecting technology adoption among rice farmers in the Mekong Delta through the lens of the local authorial managers: An analysis of qualitative data. Omonrice, 16,107-112.

[29] Zainudin, P.M.D. Hussain, Mokhtar, A., Amzah, B., Marzukhi Hashim and Abd. Ghaffar, M. B. (2012). Enam varieti padi popular MARDI. Buletin Teknologi MARDI, Bil. 1(2012), $01-10$. 